\title{
Oxidative Stress, Nuclear Factor-кB Pathway and Current Smoking in Graves' Ophthalmopathy
}

\author{
Horea Ioan Ursu ${ }^{a}$ Monica Livia Gheorghiu ${ }^{b}$ \\ a'C.I. Parhon' National Institute of Endocrinology and b'Carol Davila' University of Medicine and Pharmacy, \\ Bucharest, Romania
}

Dear Sir,

Increased generation of reactive oxygen species (ROS) is thought to play a role in the pathogenesis of Graves' ophthalmopathy (GO) $[1,2]$. Selenium (Se) is an antioxidant agent that has been recently shown to improve significantly the course of mild GO [2]. There is good evidence that oxidative stress plays a role in GO: orbital fibroblasts of GO patients have higher contents of malondialdehyde, superoxide anions and hydrogen peroxide than control orbital fibroblasts [3]. Orbital fibroblasts are recognized as the prime target cells of the autoimmune attack in GO [3].

We suggest a possible interplay between nuclear factor $-\kappa B$ $(\mathrm{NF}-\kappa \mathrm{B})$, pro-inflammatory cytokines (which activate and are activated by NF- $\kappa \mathrm{B}$, by amplifying and perpetuating orbital inflammation), ROS, Se and glucocorticoids (GC) (fig. 1) in GO [4, 5]. Many of the GC effects are mediated through an inhibition of NF$\kappa \mathrm{B}[6]$ (fig. 1). GC binding to its receptor may have a dual effect on gene activation such as activation of transcription (transactivation) or a suppression of transcription (transrepression) by interacting with NF- $\kappa \mathrm{B}$; consequently, the production of anti-inflammatory proteins is increased (transactivation), whereas the inflammatory ones are diminished (transrepression) [7].

In our view, the decreased efficacy of GC therapy in current smokers [8] might be explained - at least in part - by the antagonism GC - ROS revealed at the NF- $\kappa B$ level [4] (fig. 1). Cigarette smoking is a major source of ROS which are able to stimulate the $\mathrm{NF}-\kappa \mathrm{B}$ pathway (fig. 1), a cornerstone of immune and inflammatory response [5].

Future studies (immunosuppressive therapy plus Se) in patients with more severe GO are, at least in part, justified by the following data: (a) GC $[6,7]$ and Se [9] seem to have a similar inhib-

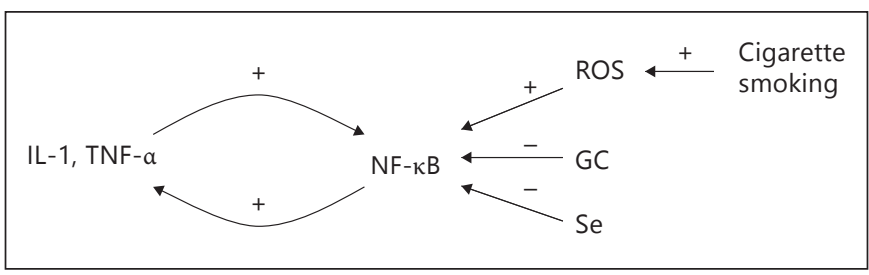

Fig. 1. Positive regulatory loop of pro-inflammatory cytokines (IL$1=$ interleukin- 1 , TNF- $\alpha=$ tumor necrosis factor $-\alpha$ ) and NF- $\kappa B$ regulated by GC, Se and ROS in GO. Cigarette smoking is a major source of ROS.

itory (possibly synergistic) effect on NF- $\kappa$ B activity (fig. 1), and (b) opposite effects on the NF- $\kappa$ B pathway of current smoking (stimulatory effect via a prooxidant effect) [5] and Se (inhibitory effect via an antioxidant action) [9] (fig. 1). Therefore, a detailed analysis of the influence of smoking upon any antioxidant therapy in patients with GO would be valuable.

\section{Disclosure Statement}

The authors have no conflicts of interest to disclose.

\section{KARGER}

E-Mail karger@karger.com www.karger.com/et
(C) 2013 European Thyroid Association

Published by S. Karger AG, Basel

2235-0640/13/0021-0069\$38.00/0
Assoc. Prof. Horea Ioan Ursu, MD, PhD

C.I. Parhon National Institute of Endocrinology

34-36 Aviatorilor Blvd, sect.1

RO-011863 Bucharest (Romania)

E-Mail horeaursu@ hotmail.com 


\section{References}

-1 Marcocci C, Leo M, Altea MA: Oxidative stress and Graves' disease. Eur Thyroid J 2012; 1:80-87.

-2 Marcocci C, Kahaly GJ, Krassas GE, Bartalena L, Prummel M, Stahl M, Altea MA, Nardi M, Pitz S, Boboridis K, Sivelli P, von Arx G, Mourits MP, Baldeschi L, Bencivelli W, Wiersinga WM: Selenium and the course of mild Graves' ophthalmopathy. N Engl J Med 2011;364: 1920-1931.

-3 Wiersinga WM: Autoimmunity in Graves' ophthalmopathy: the result of an unfortunate marriage between TSH receptors and IGF-1 receptors? J Clin Endocrinol Metab 2011;96: 2386-2394.
4 Ursu H, Badiu C, Gheorghiu ML: Selenium, mild Graves' ophthalmopathy and current smoking status. Acta Endocrinol (Buc) 2012; 8:467-470.

5 Barnes PJ, Karin M: Nuclear factor- $\kappa \mathrm{B}$ - a pivotal transcription factor in chronic inflammatory diseases. N Engl J Med 1997;336:10661071.

-6 Krassas GE, Heufelder AE: Immunosuppressive therapy in patients with thyroid disease: an overview of current concepts. Eur J Endocrinol 2001;144:311-318.
Zang S, Ponto KA, Kahaly GJ: Intravenous glucocorticoids for Graves' orbitopathy: efficacy and morbidity. J Clin Endocrinol Metab 2011;96:320-332.

$>8$ Bartalena L, Marcocci C, Tanda ML, Manetti L, Dell'Unto E, Bartolomei MP, Nardi M, Martino E, Pinchera A: Cigarette smoking and treatment outcomes in Graves' ophthalmopathy. Ann Intern Med 1998;129:632635.

9 Maehira F, Miyagi I, Eguchi Y: Selenium regulates transcription factor NF- $\kappa \mathrm{B}$ activation during the acute phase reaction. Clin Chim Acta 2003;334:163-171.

\section{Erratum}

In the article 'Side Effects of Anti-Thyroid Drugs and Their Impact on the Choice of Treatment for Thyrotoxicosis in Pregnancy' by Taylor and Vaidya [Eur Thyroid J 2012;1:176-185], the sentence in the right column on line 1, p. 179: 'Furthermore, there has been a reported case of aplasia cutis secondary to PTU exposure during pregnancy and choanal atresia [37].' should correctly read: 'Furthermore, there has been a reported case of choanal atresia secondary to PTU exposure during pregnancy [37].' 